\title{
A Case of Deep Neck Infection and Spinal Cord Abscess Related With Acupuncture
}

\author{
Junsuk Kim ${ }^{(D)}$, Seul Kim ${ }^{(D)}$, and Joo Hyun Woo ${ }^{D}$ \\ Department of Otorhinolaryngology-Head and Neck Surgery, School of Medicine, Gachon University, Gil Medical Center, \\ Incheon, Korea
}

\author{
침술 이후 발생한 심경부 감염과 척수 농양 1 예 \\ 김준석 · 김 슬 · 우주현 \\ 가천대학교 의과대학 가천의대길병원 이비인후과학교실
}

\author{
Received April 5, 2021 \\ Revised June 22, 2021 \\ Accepted June 23, 2021 \\ Address for correspondence \\ Joo Hyun Woo, MD, PhD \\ Department of Otorhinolaryngology- \\ Head and Neck Surgery, \\ School of Medicine, \\ Gachon University, \\ Gil Medical Center, \\ 38-13 Dockjeom-ro 3beon-gil, \\ Namdong-gu, Incheon 21565, Korea \\ Tel $+82-32-460-3765$ \\ Fax $+82-32-467-9044$ \\ E-mail woojh@gilhospital.com
}

A 66-year-old male patient was initially diagnosed with prevertebral and retroperitoneal abscess after cervical acupuncture. The patient underwent cervical incision and drainage, and abdominal percutaneous drainage. During postoperative care, quadriplegia was developed, and an epidural abscess of the spinal cord was identified at the fifth and sixth cervical vertebra. Urgent decompression and drainage for spinal cord abscess was performed. Sixteen weeks after decompression, quadriplegia was improved and the patient was able to walk by himself. We report, along with a literature review, a case of multiple abscesses including spinal cord abscess that developed after a cervical acupuncture.

Korean J Otorhinolaryngol-Head Neck Surg 2022;65(2):112-5

Keywords Abscess; Acupucture; Infection; Quadriplegia; Sepsis; Spinal cord.

\section{서 론}

심경부 감염은 경부의 잠재적 공간과 근막면의 감염을 뜻 하며 봉와직염이나 농양을 형성할 수 있다. ${ }^{1)}$ 심경부 감염은 위생의 개선, 보급화된 항생제 치료의 영향으로 발생률이 감 소하였지만 여전히 널리 퍼져있다. ${ }^{2}$ 근래에는 그 원인으로 치 성 감염 및 인두편도염 등 상기도감염이 가장 많다는 보고가 있으며, ${ }^{3,4}$ 조기에 적절한 치료를 시행하지 못하면 기도폐색, 경정맥염, 하행성 종격동염, 늑막과 폐의 농양, 심낭염, 경정맥 혈전, 경동맥 파열 등의 심각한 합병증을 유발할 수 있고, ${ }^{5,6}$ 해외 및 국내에서 심경부 감염에 병발되는 아주 매운 드문 합 병증으로 경추골수염, 경막외 농양이 보고된 예가 있다. ${ }^{78)}$

This is an Open Access article distributed under the terms of the Creative Commons Attribution Non-Commercial License (https://creativecommons.org/licenses/by-nc/4.0) which permits unrestricted non-commercial use, distribution, and reproduction in any medium, provided the original work is properly cited.
한방 침 요법은 통증 완화를 위한 치료 선택으로 알려져 있으며, 합병증 없는 술기를 위해서는 해부학 및 위생 관리에 대한 지식과 훈련이 필요하다. 과거 침술과 관련된 심각한 합 병증으로 균혈증, 패혈증, 척추디스크염증 등이 보고된 사례 가 있다. ${ }^{9-12)}$

저자는 침술 시행 후 전척추체공간, 척수, 후복막강 등의 다발성 농양과 함께 사지마비가 병발된 환자 1 예를 경험하여 문헌 고찰과 함께 보고하고자 한다.

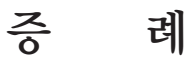

66세 남자가 내원 2일 전, 경부에 침술 시행 후 발생한 우측 경부 불편감, 우측 어깨통증을 주소로 내원하였다. 기저질환 으로 혈압과 당뇨를 않고 있었으며, 2년 전 침술 이후 발생한 후복막강 농양(retroperitoneal abscess)으로 본원에서 경피 
배액술을 시행받은 과거력이 있었다. 내원 당시 정상보행이 가능한 상태였으며, 혈압 $151 / 92 \mathrm{~mm} \mathrm{Hg}$, 심박수 80회/분, 호흡 횟수 20 회/분, 체온은 $36.6^{\circ} \mathrm{C}$ 였다. 혈액검사에서 백혈구 $10650 / \mathrm{mm}^{3}$, 호중구 비율 $89.1 \%$, 고감도C반응단백(high sensitive C-reactive protein) $11.09 \mathrm{mg} / \mathrm{dL}$ 였다. 후두경 검사 에서 인두부위에 짙은 가래와 점막 발적, 그리고 윤상연골 뒤 의 후인두벽 부종이 관찰되었다. 경부 전산화단층촬영 결과 5 번, 6번 경추체 전방부위 농양이 관찰되었다(Fig. 1A). 농양 은 앞쪽으로 변연의 구획된 조영증강이 관찰되었고 뒤쪽으로 는 경추체와 맞닿아 있어 위험공간과 전척추 공간의 농양이 의심되었다(Fig. 1B). 복부 전산화단층촬영에서 후복막강의 $7.5 \mathrm{~cm}$ 농양이 관찰되었다(Fig. 2). 심경부 농양에 대해 우측 전경부 접근법으로 절개배농을 시행하였다. 수술 소견에서 후인두공간(retropharyngeal space)의 감염소견은 없었으며 익상근막(alar fascia)이 팽륜되어 있었다. 팽균된 익상근막을 절개하였을 때 다량의 농양이 배출되었고 척추체가 노출되어 익상근막 뒤쪽의 위험공간(danger space)과 전척추공간(prevertebral space)에서 발생한 농양으로 확인되었다. 충분한 세 척 후 배액관을 삽입하고 수술을 종료하였다. 후복막강 농양 에 대해서는 영상의학과에 의뢰하여 경피적 배농술을 시행 하였다. 수술 후 1 일째 배뇨장애와 양측 하지마비가 발생하였 고, 마비는 점진적으로 상행하여 수술 후 2일째 사지마비로 진행 및 혼자 앉지 못하는 상태였다. 경흉추 자기공명영상촬 영 결과 경추 5,6 번 위치에서 척수경막외 농양(epidural abscess of the spinal cord)이 확인되었으며(Fig. 3), 배농과 감 압을 위해 $4,5,6,7$ 번 경추와 1 번 흥추에 대해 추궁판 성형 술, 추간공확장술을 시행하였다.
혈액배양과 경부 농배양 검사에서 황색포도상구균(Staphylococcus aureus)이 동정되었다. 혈액검사 결과 섬유소원분 해산물 정량(fibrinogen degradation product 정량) $11.6 \mathrm{ug} /$ $\mathrm{mL}$, 섬유소원(fibrinogen) $558 \mathrm{mg} / \mathrm{dL}, \mathrm{D}$ 이합체(D-dimer) $6055 \mathrm{ng} / \mathrm{mL}$ fibrinogen equivalent units로 상승되었고, 항 트롬빈III (anti thrombin III) 62.0\%가 감소되었으며, 혈압은 $68 / 60 \mathrm{~mm} \mathrm{Hg}$ 으로 떨어져 패혈성 쇼크 진단하 사망 가능성 이 우려되어 감염내과로 전과 되었다. 절개배농 5일 후 백혈구 $5830 / \mathrm{mm}^{3}$, 호중구 비율 $63.8 \%$, 고감도C반응단백 $2.88 \mathrm{mg} /$ $\mathrm{dL}$ 로 호전되었다. 척추 수술 6주 후 포괄적인 재활치료를 위 해 재활의학과로 전과 하였으며, 수술 12 주 후 상하지 운동성 이 회복되어 지팡이 보조하에 보행 가능한 상태로 지속적인 재활치료 중이다.

\section{고 찰}

본 연구는 한방 침 시술 이후 혈행성 감염을 통한 다양한 부위에 농양이 발생한 환자에 대한 보고이다. 특히 척수에 농 양이 발생하여 환자에 재앙적인 이환이 발생한 점에 대해 주 지할 필요가 있다.

심경부 감염은 복잡한 경부 해부학을 기반으로 다양한 감 염경로를 가지며, 구강 또는 인후두 감염이 주변 공간으로 확 장되어 발생하는 경우가 많다. ${ }^{13)}$ 하지만 본 환자의 경우 인후 두 감염을 의심할 만한 증상과 징후가 없었고 심각한 전척추 공간 농양이 있었음에도 불구하고 후인두공간은 감염 소견 이 없어 인후두 감염에 의한 원인을 배제할 수 있었다.

침술에 의한 균혈증으로 인해 이차적으로 후복막강 농양,
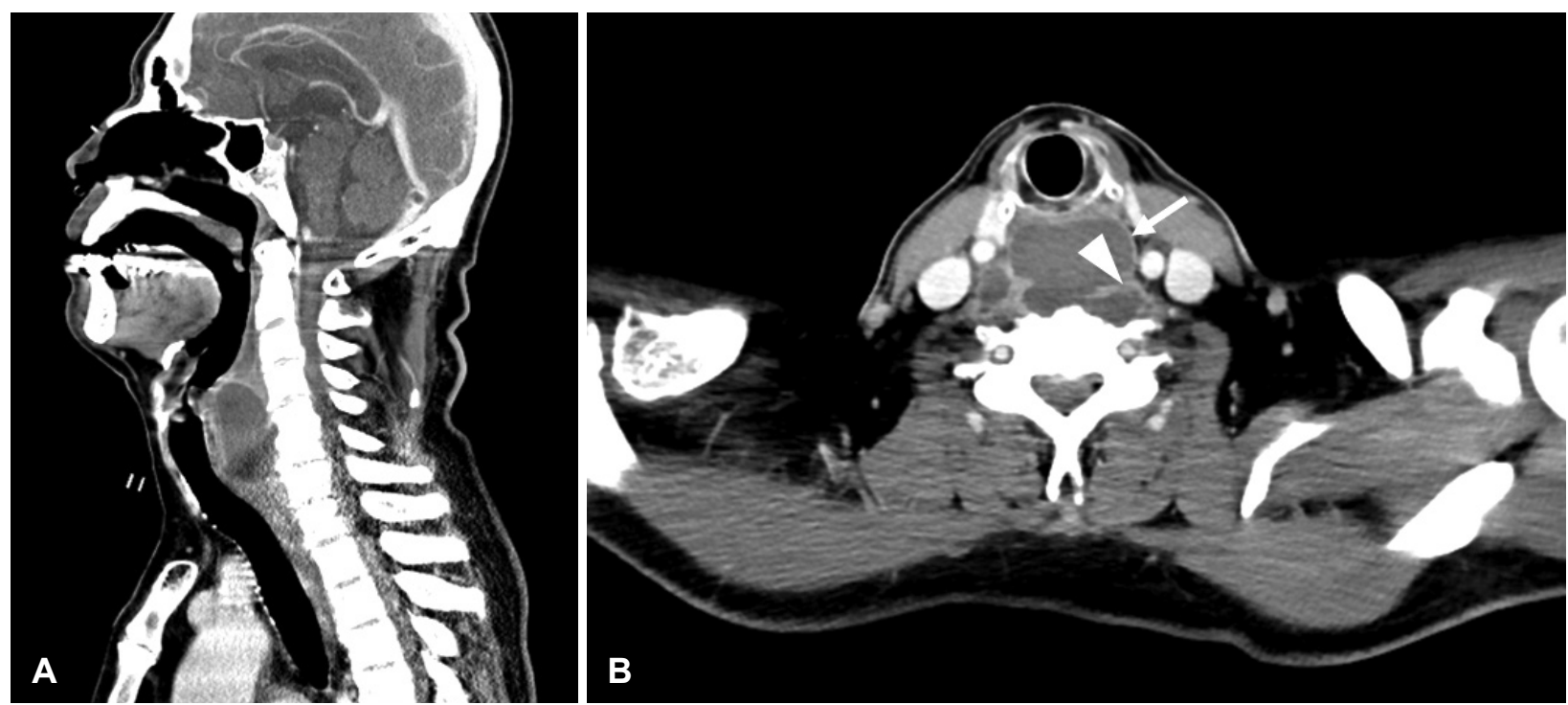

Fig. 1. Enhanced neck CT. A: In the sagittal view, prevertebral abscess was shown at the level of C5 and C6 vertebra. B: In the axial view, abscess was septated by ala fascia (arrow) and prevertebral fascia (arrowhead) 


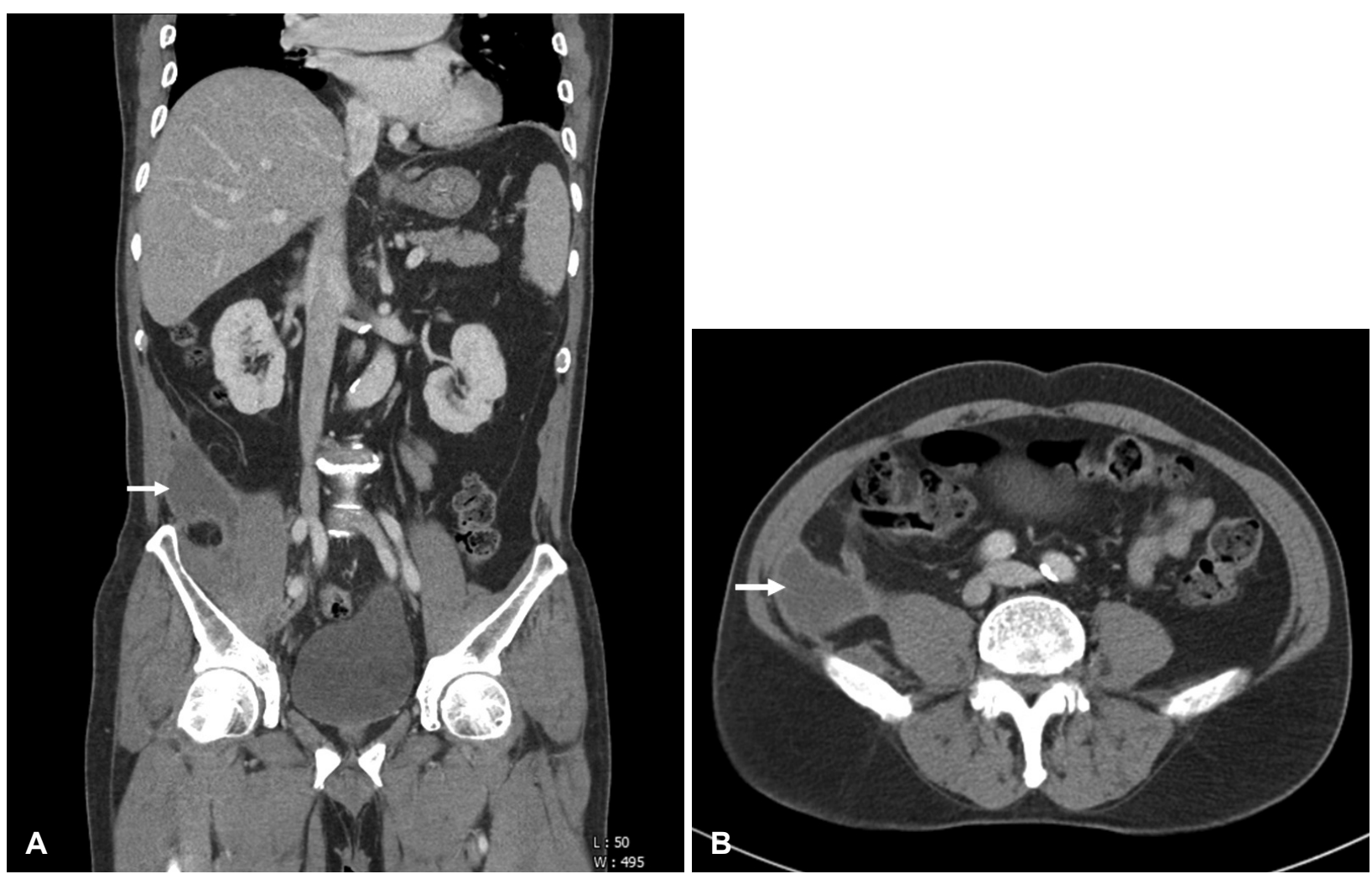

Fig. 2. Enhanced abdominal CT. About $7.5 \mathrm{~cm}$ sized retroperitoneal abscess (arrow) was found at the right lower quadrant abdomen in coronal (A) and axial (B) view.

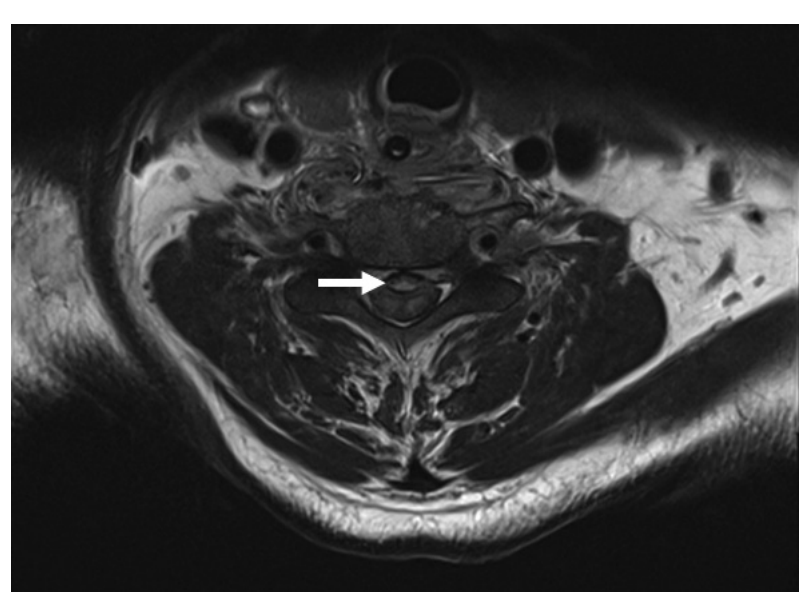

Fig. 3. T2-weighted MR image of cervical spine. Anterior epidural abscess (arrow) with cord compression was found at level of the fifth cervical spine.

요근 농양, 척수 경막외 농양 등의 전신적 합병증이 발생할 수 있으며, 황색포도상구균이 가장 흔한 원인균으로 알려져 있 다. ${ }^{14)}$ 패혈증에 따른 전신의 국소 농양 형성 속도는 매우 빠를 수 있으며 사지마비가 발생한 후에야 척추염, 척수 경막외농 양을 발견하는 경우가 있다. ${ }^{10)}$ 또한 패혈증 환자에서 인후두 감염이 없고 혈액검사 소견은 개선을 보이는 상태에서도 사 지마비, 경부통, 경직을 보이면서 척추염, 후인두 농양이 발견
된 보고도 있다. ${ }^{8)}$ 본 증례의 경우 침을 맞은 병력과 이후 발 생한 혈액학적, 혈역학적 상태에서 패혈증을 의심할 만한 소 견이 나타났으며, 배양검사에서 황색포도상구균이 동정되어 침술에 의해 이차적으로 발생한 전신의 국소 농양을 의심할 수 있었다. 특히 침 시술을 받은 이후 2일이라는 비교적 짧은 시간에 경부에 심각한 농양이 형성되었음을 확인하였으며, 그 하루 뒤에 다시 척수 농양에 의한 마비가 발생할 정도로 급작스런 진행을 보였다. 더욱이 전척추공간 농양에 대한 수 술과 항생제 치료를 시행 중임에도 척수 농양이 진행하였다. 척수 농양은 심경부 감염에서 흔히 시행하는 경부 전산화단 층촬영으로 진단이 불가능 하다. ${ }^{15)}$ 진단을 위해서는 척수에 대한 자기공명영상 검사를 해야하는데 의심이 되지 않는 상 태에서 이를 일반검사로 시행하기는 어렵다. ${ }^{15)}$ 따라서 척수 농 양의 경우 환자의 신체검사를 통해 임상의가 의심할 때에만 진단될 가능성이 높다. 본 증례의 경우 응급실 내원 시 거동 이 가능한 상태였기 때문에 의심하기 어려운 상태였다. 또한 경부 절개 배농 이후에는 패혈증에 따른 혈역학적 불안정과 기관절개술 등으로 인해 중환자실에서 침상안정 중이었다. 주 치의가 사지근력에 대한 신체검사를 통해 조기에 척수 농양 을 진단하지 못했다면 사지마비와 같은 심각한 장애가 남을 수 있는 상태였다. 따라서 패혈증이 동반된 심경부 감염의 경 
우에는 이비인후과 영역의 국소 감염에 대한 상태가 호전된 다 하더라도 사지의 근력, 감각이상, 배뇨장애 등이 발생하지 않는지 환자의 신경학적 증상에 유의하고 사지의 감각과 근 력에 대한 신체검사를 지속적으로 시행하는 것이 바람직할 것으로 판단된다.

\section{Acknowledgments}

None

\section{Author Contribution}

Conceptualization: Junsuk Kim, Joo Hyun Woo. Data curation: Seul Kim. Formal analysis: Seul Kim. Investigation: Junsuk Kim. Visualization: Junsuk Kim. Writing — original draft: Junsuk Kim. Writing—review \& editing: Junsuk Kim, Joo Hyun Woo.

\section{ORCIDs}

Joo Hyun Woo

Junsuk Kim

https://orcid.org/0000-0002-8584-563X

Seul Kim

https://orcid.org/0000-0002-4203-0131

https://orcid.org/0000-0002-5538-6372

\section{REFERENCES}

1) Wang LF, Kuo WR, Tsai SM, Huang KJ. Characterizations of lifethreatening deep cervical space infections: A review of one hundred ninety-six cases. Am J Otolaryngol 2003;24(2):111-7.

2) Amar YG, Manoukian JJ. Intraoral drainage: Recommended as the initial approach for the treatment of parapharyngeal abscesses. Otolaryngol Head Neck Surg 2004;130(6):676-80.

3) Huang TT, Liu TC, Chen PR, Tseng FY, Yeh TH, Chen YS. Deep neck infection: Analysis of 185 cases. Head Neck 2004;26(10):85460.

4) Kim YS, Park JH, Chun SS, Han DY, Kim JE, Lee BD. Clinical analysis of deep neck infection. Korean J Otorhinolaryngol-Head Neck Surg 2010;53(10):627-31.

5) Koivunen P, Löppönen H. Internal carotid artery thrombosis and Horner's syndrome as complications of parapharyngeal abscess. Otolaryngol Head Neck Surg 1999;121(1):160-2.

6) Sethi DS, Stanley RE. Deep neck abscesses--changing trends. J Laryngol Otol 1994;108(2):138-43.

7) Jang YJ. Retropharyngeal abscess associated with osteomyelitis of the cervical spine and an epidural abscess. Korean J OtorhinolaryngolHead Neck Surg 1997;40(3):435-9.

8) Kusunoki $T$, Ito $S$, Iizuka $T$, Ono $N$, Ikeda $K$. A case of retropharyngeal abscess with spondylitis causing tetraplegia. Clin Pract 2012;2(2):123-4.

9) Robinson A, Lind CR, Smith RJ, Kodali V. Atlanto-axial infection after acupuncture. Acupunct Med 2016;34(2):149-51.

10) Bang MS, Lim SH. Paraplegia caused by spinal infection after acupuncture. Spinal Cord 2006;44(4):258-9.

11) Cho YP, Jang HJ, Kim JS, Kim YH, Han MS, Lee SG. Retroperitoneal abscess complicated by acupuncture: Case report. J Korean Med Sci 2003;18(5):756-7.

12) Chiang GS, Tong K. Acupuncture causing methicillin-sensitive Staphylococcus aureus spondylodiscitis resulting in bacteremia and bacteriuria. J Am Geriatr Soc 2014;62(11):2221-2.

13) Vieira F, Allen SM, Stocks RM, Thompson JW. Deep neck infection. Otolaryngol Clin North Am 2008;41(3):459-83.

14) Ernst E, White A. Life-threatening adverse reactions after acupuncture? A systematic review. Pain 1997;71(2):123-6.

15) Baker AS, Ojemann RG, Swartz MN, Richardson EP Jr. Spinal epidural abscess. N Engl J Med 1975;293(10):463-8. 